\title{
Cerebral Infarction in Autopsies of Chagasic Patients with Heart Failure
}

\author{
Roque Aras, José Alberto M. da Matta, Gildo Mota, Irênio Gomes, Ailton Melo \\ Salvador, BA - Brazil
}

\begin{abstract}
Objective -To determine the frequency of encephalic infarction and its contribution to lethality in patients with Chagas' disease and heartfailure.

Methods - Medical records and autopsy reports of patients with Chagas' disease complicated by heart failure, who died at the Professor Edgar Santos Hospital of the Federal University of Bahia in the past 45 years were retrospectively analyzed. Data comprised information regarding the clinical history on hospital admission, complementary and anatomicopathological examinations, including the presence of encephalic infarction, the impaired region, and the cause of death.
\end{abstract}

Results -Ofthe 5,447 autopsies performed, 524 were in patients with heart failure due to Chagas' disease. The mean age was 45.7 years, and 51 (63\%) patients were of the male sex. The frequency of encephalic infarction was $17.5 \%$, corresponding to 92 events in 92 individuals, 82 (15.8\%) of which involved the brain, $8(1.5 \%)$ involved the cerebellum, and $2(0.4 \%)$ involved the hypophysis.

Conclusion - Cerebral infarction has been a frequent finding in autopsies of chagasic patients with heart failure, and it has been an important cause of death in our region. The presence of cerebral infarction and its complications have been associated with death in $52 \%$ of the cases studied.

Key words: Chagas' disease, cerebral infarction, frequency, autopsies

Universidade Federal da Bahia - Salvador

Mailing address: Roque Aras - Av. Juracy Magalhães Jr, 2426/104 - 41940-060 Salvador, BA, Brazil - E-mail: raras@ufba.br

English version by Stela Maris C. e Gandour

Received - 7/11/02

Accepted - 11/20/02
Chagas' disease is one of the major causes of heart failure in South America because of the elevated prevalence of that infection on the continent. Involvement of the heart occurs in approximately $30 \%$ of the individuals with positive serology for T. cruzi infection, and this heart involvement may result in arrhythmias, heart failure, thromboembolism, and sudden death ${ }^{1-3}$.

Thromboembolic phenomena are frequently reported in congestive heart failure due to Chagas' disease. Approximately $20 \%$ of the individuals diagnosed with heart failure developed, at some point in their evolution, systemic or pulmonary thromboembolism ${ }^{4,5}$. These patients are under a high risk of developing intracavitary thrombosis and consequent thromboembolism because of the dilation of the cardiac chambers, slow blood flow, presence of ventricular aneurysm, emboligenic arrhythmias, and severity of heart failure $^{6,7}$.

Thrombosis and embolic events are found in 40 to $60 \%$ of the autopsies of chagasic patients with heart failure, and they have been reported even in the absence of signals and symptoms of heart disease ${ }^{8-11}$. Chagas' disease, because of its epidemiological frequency and great emboligenic potential, is an important risk factor for stroke in our country ${ }^{12-14}$. Cerebral infarction has been reported in 5 to $15 \%$ of the autopsies of chagasic individuals ${ }^{15-18}$.

The clinical relevance of strokes, due to their frequency, their possibility of being a cause of death, and their severe complications, is seldom emphasized in select groups of high-risk patients, such as those with heart failure. In an extensive case series of autopsies of chagasic individuals, Oliveira et al ${ }^{19}$ reported $39(6 \%)$ individuals with cerebral infarction, 11 of whom had infarction characterized as the cause of death.

The objective of this study was to report the frequency of cerebral infarction in autopsies of chagasic individuals with heart failure and its possible implications in the causal mechanisms of death.

\section{Methods}

The medical records and autopsy reports of patients 
with Chagas' disease complicated by heart failure, who died at the Professor Edgar Santos Hospital of the Federal University of Bahia (HUPES/UFBA) from 1956 to 2001, were retrospectively analyzed.

The HUPES/UFBA is a referral center for medical assistance, teaching, and research on chagasic patients in the northeastern region of Brazil. Autopsies of the patients who die there are routinely performed.

The forms of data collection comprised the following information: clinical history; sex; age; complementary examinations; anatomicopathological findings, including the presence of infarction, the encephalic region involved, and the presence of thrombosis in left cardiac chambers; associated diseases; clinical complications during hospitalization due to encephalic infarction; cause of death according to the pathologist; and the clinical implications of the encephalic infarction in the mechanism of death.

Descriptive statistics was used to analyze the variables and their distribution inside the study sample, with calculation of the means, proportions, and the measures of dispersion. The chi-square test and the Fischer exact test were used to compare the frequencies between the groups. The Student $t$ test was used to compare the means. Relative risk and confidence intervals were calculated for the variables studied. The results found were considered statistically significant for $\mathrm{P}<0.05$.

\section{Results}

During the period studied, 5,447 autopsies were performed at the HUPES/UFBA, 524 (9.6\%) of which were in patients with Chagas' disease, who died with the diagnosis of heart failure. In $92(17.5 \%)$ patients, encephalic infarction was identified, and, in 82 (15.8\%) patients, the infarction was located in the brain. The distribution of the frequency of encephalic infarctions according to the region impaired was as follows: cerebral infarction, $89.1 \%$ of the cases; cerebelar infarction, $8.7 \%$; and hypophyseal infarction, $2.17 \%$.

The mean age of the entire sample was 38.4 years, and the mean age in the population with encephalic infarction was 45.7 years $(\mathrm{dp}=16.4)$, ranging from 17 to 82 years. Of the patients with cerebral infarction, $64 \%$ were less than 50 years old and $63 \%$ were males.

Eighty-one autopsy reports and medical records, which are part of the analysis of the clinical implications of cerebral infarction, were recovered. The major immediate causes of death reported by the pathologists were as follows: congestive heart failure in $36(44.4 \%)$ patients; pulmonary embolism in 20 (24\%); acute cerebral infarction in 15 (18\%); bronchopneumonia in $8(9.8 \%)$; and cardiac arrhythmia in $3(3.7 \%)$ patients.

Cerebral infarction was reported in the medical records as previously diagnosed in only $25(31 \%)$ individuals. The presence of acute neurologic symptomatology or sequelae due to cerebral infarction was reported in $31(38 \%)$ autopsies.

The analysis of the medical records and autopsy reports showed that cerebral infarction was the cause directly related to death in 15(18\%) individuals, was mentioned in 25 clinical histories, and reported in 31 autopsies. It may have contributed to the infectious complications described in 8 cases, and, in some patients, the events were simultaneous. Cerebral infarction contributed directly or was associated with the mechanisms of death in $52 \%$ of the individuals.

When the possible risk factors for cardiovascular and cerebral diseases are analyzed in the study sample, age $>40$ years and the presence of thrombosis in the left cardiac chambers (atrium, ventricle, left ventricular tip) were associated with cerebral infarction with $\mathrm{P}<0.001$. Table I shows the frequency, relative risk, and confidence interval of the variables analyzed.

The most frequently associated diseases and lifestyle habit reported in the autopsies were as follows: diabetes mellitus ${ }^{3}$, arterial hypertension ${ }^{8}$, dyslipidemia ${ }^{2}$, atherosclerosis $^{4}$, smoking ${ }^{3}$, and obesity ${ }^{2}$. Atrial fibrillation was reported in 8 medical records, corresponding to $10 \%$ of the autopsies.

\section{Discussion}

Cerebral infarction in Chagas' disease has been described by several authors in autopsy reports, clinical case series, and cohort studies of individuals with the undetermined form or, more commonly, in the advanced phase of the disease with chronic heart disease and congestive syndro$\mathrm{me}^{2,13,14}$.

Our results are in accordance with those of other autopsy studies previously published, in which the frequency of cerebral infarction varied from 5 to $15 \%$, evidencing the great cerebral emboligenic potential of the disease $4,9,12,20$. On the other hand, not only the high number of autopsies performed may have contributed to the greater frequency of

\begin{tabular}{|c|c|c|c|c|}
\hline \multicolumn{5}{|c|}{$\begin{array}{l}\text { Table I - Analysis of risk factors for cerebral infarction in the sample } \\
\text { of } 524 \text { chagasic individuals with heart failure }\end{array}$} \\
\hline Variable & $\begin{array}{l}\text { Prevalence of cerebral } \\
\quad \text { infarction }(\%)\end{array}$ & $\mathrm{RR}$ & $95 \% \mathrm{CI}$ & $\mathrm{P}$ \\
\hline \multicolumn{5}{|l|}{ Age (years) } \\
\hline$>40$ & 21.2 & 1.72 & $1.16-2.55$ & 0.007 \\
\hline$\leq 40$ & 12.4 & & & \\
\hline \multicolumn{5}{|l|}{ Sex } \\
\hline male & 15.9 & 0.97 & $0.64-1.46$ & 0.88 \\
\hline female & 16.4 & & & \\
\hline \multicolumn{5}{|c|}{ Atrial fibrillation or flutter } \\
\hline yes & 21.1 & 1.19 & $0.68-2.09$ & 0.55 \\
\hline no & 17.7 & & & \\
\hline \multicolumn{5}{|c|}{ Ventricular arrhythmias } \\
\hline yes & 16.4 & 0.76 & $0.49-1.19$ & 0.24 \\
\hline no & 21.5 & & & \\
\hline \multicolumn{5}{|c|}{ Intraventricular blocks } \\
\hline yes & 16.8 & 0.68 & $0.42-1.12$ & 0.14 \\
\hline no & 24.6 & & & \\
\hline \multicolumn{5}{|c|}{ Tip aneurysm } \\
\hline yes & 18.6 & 1.31 & $0.87-1.96$ & 0.19 \\
\hline no & 14.2 & & & \\
\hline \multicolumn{5}{|c|}{ Left chamber thrombosis } \\
\hline yes & 22.4 & 2.12 & $1.40-3.21$ & $<0.001$ \\
\hline no & 10.6 & & & \\
\hline
\end{tabular}


encephalic infarctions found in our case series, but also the presence of risk factors, such as the elevated prevalence of Chagas' disease in endemic areas of the northeastern region of Brazil, the male sex, and the severity of the clinical presentation of heart failure, may have also played an important role ${ }^{21,22}$.

Of the possible risk factors for cardiovascular and cerebral diseases that could be analyzed in this autopsy series, we observed that, contrary to findings in other series, chagasic individuals had a low mean age and lower frequency of comorbidities, which might be attributed to the long period of observation of the study, to the evolutional characteristics of the infection by T. cruzi affecting younger people, and to the severity in the progression of symptoms .

In our case series, age $>40$ years and the presence of thrombosis in the left chambers were associated with cerebral infarction, which is in accordance with findings of other authors, who suggest that chagasic patients with advanced heart failure, thrombosis in the left cardiac chambers, atrial fibrillation, ventricular arrhythmias, previous embolism, and ventricular aneurysm are under a high risk for ischemic stroke ${ }^{15,23,24}$.

Neurological symptoms and sequelae were reported in the clinical history and autopsy reports in only $31 \%$ and $38 \%$ of the cases, respectively. These results show that many hospitalized patients who evolved to death were not correctly diagnosed as having cerebral infarction. Other series reported similar results, when they observed that, despite the high frequency of systemic embolic events in autopsies, most of these events were not diagnosed during hospitalization, impairing efficiency in prevention and treatment ${ }^{4,5,9}$.

When analyzing cohort studies carried out to determine the incidence of systemic thromboembolism in chagasic individuals with heart failure, no significant difference was observed in the low rates found in that disease as compared with those of other causes of heart failure ${ }^{23-27}$.

Efficiency in preventing thromboembolic phenomena through anticoagulation for patients with heart failure remains controversial ${ }^{4,6,26,28}$. The early diagnosis and adequate treatment in subgroups of elevated embolic risk may reduce the complications and improve the quality of life of these individuals.

In conclusion, cerebral infarction in the chagasic patient with heart failure is frequent and of great importance due to clinical implications, mortality, and neurological sequelae.

\section{References}

1. Organização Mundial da Saúde: Control de la Enfermidad de Chagas, Série de Informes Técnicos 1991;811.

2. Brener Z, Andrade Z, Barral-Neto M.Trypanosoma cruzie Doença deChagas. $2^{a}$ ed. Rio de Janeiro, Guanabara Koogan: 2000

3. Simões MV, Almeida Filho OC, Pazin Filho A, et al. Insuficiência cardíaca na doença de Chagas. Rev Soc Cardiol ESP 2000; 10.

4. Barretto ACP, Canesin M. Fenômenos embólicos de origem cardíaca: incidênciae prevençãona insuficiência cardíaca congestiva. Rev Soc Cardiol Estadode São Paulo 1997; 7.

5. Roberts WC, Siegel RJ, McManus BM. Idiophatic dilated cardiomyopathies: analysis of 152 necropsy patients. Am J Cardiol 1987; 60: 1340-55

6. Dunkman WB, Johnson GR, Carson PE, Bhat G, Farrel L, Cohn J. Incidence of thromboembolism events in congestive heart failure. Circulation 1993;87 (Suppl.VI):94-101.

7. Williams JF, Bristow MR, Fowler MB, et al. ACC/AHA guidelines for the evaluation and management of chronic heart failure: report of the American College of Cardiology/American Heart Association. Task Force on Pratice Guildelines (Committee on Evaluation and Management of Heart Failure). J Am Coll Cardiol 1995; 26:1376-98.

8. AndradeZ\& Sadigursky M. Tromboembolismoem chagásicos seminsuficiência cardíaca. Gaz Méd 1971; 71:59-64.

9. Barretto ACP. Tromboembolismo na insuficiência cardíaca. Rev Soc Cardiol Estado de São Paulo 2000; 10:23-32

10. Nussenzveig I, Spina-França-Neto A, Wajchemberg BL, Macruz R, Timoner J, Serro Azul LG.. Acidentes vasculares cerebrais embólicos na cardiopatia chagásica crônica. Arq Neuropsiquiatr 1953; 11:386-402.

11. Arteaga-Fernandes E, Barreto ACP, Ianni BM, et al. Trombose cardíaca e embolia em pacientesfalecidosdecardiopatiachagásicacrônica.ArqBrasCardiol 1989;52:189-92.

12. Rey RC, Lepera SM, Kholer G, Monteverde DA, Sica REP. Embolia cerebral de origen cardíaco. Medicina 1992; 52:202-6.

13. Carol-Artal FJ, Melo M, Vargas AP. Stroke of cardioembolic origin in Chagas disease. Rev Neurol 2001;33:311-4.

14. Castagnino HE, Cicco JA, Fauth M, Thompson AC. Miocardiopatia emboligena en la enfermedad de Chagas. Medicina 1978;38:35-9.
15. Braga JC, Labrunie A, VillaçaF, Nascimento E, Quijada L. Thromboembolism in chronic Chagas'heart disease. São Paulo Med J 1995; 1 13: 862-6.

16. Neiva A \& AndradeZA. Embolia cerebral em portadores de miocardite crônica chagásica. Hospital 1962;61:373-9.

17. Romano Junior D, Silva AQ, Cunha GP, Oliveira PF. Tromboembolismo na doença de Chagas. Rev Med PR 1956; 25:263-76.

18. Sobral Neto J, Duarte LCA, Bressane JF, Mattos JV, Miziara HL, Marins N. Tromboembolismo na cardiopatia crônica. Arq Bras Cardiol 1977; 30: 209-14.

19. Oliveira JSM, Araújo RRC, Navarro MA, Muccillo G. Cardiac thrombosis and thromboembolism in chronic Chagas'heart disease. AmJCardiol 1983;52: 147-51.

20. Carvalho JAM. Tromboembolismo na doença de Chagas em Pernambuco - considerações em torno da incidência em material de necrópsia. Rev Bras Malaria Doenças Tropicais 1963;611-6.

21. Aras R, Veiga M, Gomes I, et al. Prevalence of Chagas' disease in Mulungu do Morro, Northeastern Brazil. Arq Bras Cardiol 2002; 78: 441-3.

22. Barretto ACP, Arteaga E, Mady C, Ianni BM, Bellotti G, Pileggi F. Sexo masculino: fator prognóstico na doença de Chagas. Arq Bras Cardiol 1993;60:225-7.

23. Sousa AS, Alencar AT, Moreno AH, Xavier S. Incidência e preditores de acidente vascular cerebral em uma coorte de 602 pacientes portadores de doença de Chagas. LIV Congresso Brasileiro de Cardiologia. http://www.cardiol.br/ congresso/liv/temas/aprov/265.asp.

24. Bestetti R. Stroke in a hospital-derived cohort of patients with chronic Chagas'disease. Acta Cardiol 2000; 55:33-8.

25. Diet F, Erdmann E. Thromboembolism in heart failure: who should be treated? Eur J Heart Fail 2000; 2:355-363.

26. Katz SD, Marantz PR, Biasucci L, Jondeau G, Lee K, Brennan C, Lejemtel TH Low incidence of strole in ambulatory patients with heart failure: a prospective study. Am Heart J 1993; 126:141-6.

27. Albanesi Filho FM, Gomes Filho JBM. O tromboembolismo em pacientes com lesão apical da cardiopatia chagásica crônica. Rev Port Cardiol 1991; 10:35-42.

28. Lapeyre AC, Steele PM, Kazmier FJ, Chesebro JH, Vlietstra RE, Fuster V. Systemic embolism in chronic left ventricular aneurysm: incidence and role of anticoagulation. J Am Coll Cardiol 1985;6:534-8. 